Analitika: Jurnal Magister Psikologi UMA, Vol. 10 (2) Desember (2018)

ISSN: 2085-6601 (Print), ISSN: 2502-4590 (Online),

DOI: http://dx.doi.org/10.31289/analitika.v10i2.2034

\title{
ANALITIKA
}

Jurnal Magister Psikologi UMA

Available online http://ojs.uma.ac.id/index.php/ analitika

\section{Instagram and Mental Health of Institut Agama Islam Negeri Students in Kendari}

\section{Instagram dan Kesehatan Mental pada Mahasiswa Institut Agama Islam Negeri Kendari}

\author{
Nuraeni Aprilia Mondoano*, Ros Mayasari \& Fahmi Gunawan \\ Institut Agama Islam Negeri Kendari, Indonesia \\ Diterima: November 2018, disetujui: Desember 2018, dipublish: Desember 2018
}

*Corresponding author: E-mail: mayagayo@yahoo.com

\begin{abstract}
This research aims to analyze mental health of the students using Instagram at Institut Agama Islam Negeri Kendari as the biggest Islamic Higher Education in Southeast Sulawesi. The researchers interviewed 50 students. The research result indicates that the students using Instagram with high intensity have negative mental health. It proved by their inaccurate perception to their self-representation. They assess and feel their existence based on how many followers typing "love" in their post. Even, they will feel so deeply disturbed, unhappy and angry if anyone criticized their post and when their followers begin to decrease. They also will frequently wait for how many people are going to respond their new post. They seriously make their Instagram story as a means to represent themselves to others as desired. Instagram usage activities need to be taught well so as not to have a negative impact on students, especially for their mental health.
\end{abstract}

Keywords: Instagram, Mental Health, College Students

\begin{abstract}
Abstrak
Penelitian ini bertujuan untuk menganalisis kesehatan mental para siswa yang menggunakan Instagram di Institut Agama Islam Negeri Kendari sebagai Pendidikan Tinggi Islam terbesar di Sulawesi Tenggara. Para peneliti mewawancarai 50 siswa. Hasil penelitian menunjukkan bahwa siswa yang menggunakan Instagram dengan intensitas tinggi memiliki kesehatan mental negatif. Itu dibuktikan dengan persepsi mereka yang tidak akurat terhadap representasi diri mereka. Mereka menilai dan merasakan keberadaan mereka berdasarkan berapa banyak pengikut mengetik "cinta" di posting mereka. Bahkan, mereka akan merasa sangat terganggu, tidak bahagia dan marah jika ada yang mengkritik jabatan mereka dan ketika pengikut mereka mulai berkurang. Mereka juga akan sering menunggu berapa banyak orang yang akan menanggapi posting baru mereka. Mereka serius membuat cerita Instagram mereka sebagai sarana untuk mewakili diri mereka sendiri kepada orang lain seperti yang diinginkan. Kegiatan penggunaan Instagram perlu diajarkan dengan baik agar tidak memiliki dampak negatif pada siswa, terutama untuk kesehatan mental mereka.
\end{abstract}

Kata Kunci: Instagram, Kesehatan Mental, Representasi Diri, Kesejahteraan, Mahasiswa

How to Cite: Mondoano, N.A. Ros, M. \& Fahmi, G. (2018), Instagram and Mental Health of IAIN's Students in Kendari, Analitika: Jurnal Magister Psikologi UMA, 10 (2): 104 - 110 


\section{INTRODUCTION}

According to World Bank data updated on June $2^{\text {nd }}, 2016$, in 2013 $14.94 \%$ of the Indonesian population were active users of the internet. The use of internet not only contributes positive impact for the users, but also contributes potentially negative impact which cannot be underestimated (Kim \& Lee, 2011; Gunawan, 2012). Numerous studies have been conducted to investigate the effect of the internet indicating alarming result. Use of the Internet without self-control negatively affects the social, psychological and even physical aspects of the users (Pujazon-Zazik \& Park, 2010); Wilson, Fornasier \& White, 2010).

Internet impact on mental health is also one of researchers' concerns. United Kingdom's Royal Society of Public Health published the results of research conducted on 1,479 people aged 14-24 years from various regions in the United Kingdom. In this survey, the respondents answered 14 about the difference of the influence of media use on physical and mental health of users. Some conclusions can be drawn from this survey. Instagram gives the most potentially bad effects on mental health and mental compared to other social media such as Twitter, Facebook, or YouTube Snapchat (Siddiqui \& Singh, 2016; Bakker, Kazantzis, Rickwood \& Rickard, 2016; Jang, Park \& Song, 2016). What happen to Instagram users in Indonesia? Based on the report of Kompas.com, Indonesia is the country with the most Instagram users in Asia Pacific. Of 700 monthly active users (MAU) globally, 45 million of which are from Indonesia. This number is considerably increase compared to
January 2016. This article has been published in Kompas.com entitled "Indonesia, the most active Instagram Users in Asia-Pacific" (Retrieved from https://tekno.kompas.com/read/2017/0 7/27/11480087/indonesia-penggunainstagram-terbesar-se-asia-pasifik).

The number of Instagram users as described above makes the researcher interested in discussing this issue. On the one hand, based on the World Bank and EPJ data science, Instagram turned out to create negative impact on a person's mental health (Reece \& Danforth, 2017). The observation results indicate that students of IAIN Kendari are also Instagram users. The main reason of using Instagram is to be updated or they do not want to be left behind. Most of them spend time just to access their Instagram account which makes them reluctant to learn and get rest in the night. Intagram turns out to have attractive features for the users to keep accessing it. The users tend to express themselves using this social media, compete to get as many as followers, or to get love and response from what they have posted on their account. Apart for self-expression, they also often look at someone's vacation photos, as a result, they tend to look for more interesting places and post them on their Instagram account.

Research on Instagram and mental health in Indonesia has been done by Landesi Andarwati who examines selfimage in terms of the intensity of the Instagram users in class XI of SMAN 9 Yogyakarta (Andarwati, 2016). The results of their research focus on selfimage taking up 35\%-62\%, and 3\% did 
not highlight the self-image, also focused on the intensity of the use of Instagram up to $6 \%-76 \%$ which are very active users, and $1 \%-17 \%$ do not so intense in using Instagram. Then there is also a research conducted by Bungan Nurika who examines the relationship between the Self Concept Confidence of Adolescents who Upload photos on Instagram Selfies. Based on the research, the self-confidence of the teenagers taking up $23 \%$ indicates that there are some other factors affecting their selfconfidence (Nurika, 2016).

The focus of this study is also to acquire Instagram users' profile in higher education, especially Islamic higher education and to know the negative impacts of Instagram on the users among the students who are at the age of potential to develop the ability of selfregulation and critical thinking. In contrast to previous studies, this study does not focus on the symptoms, but in general on the mental health of the users of Instagram at the State Islamic Institute (IAIN) of Kendari.

\section{METHODOLOGY}

This study uses a qualitative approach. The research subjects were the students of IAIN Kendari. Data were collected through open-ended questionnaire to map the usage patterns of Instagram users. Open-ended questionnaire includes some questions about the background of the respondents in using Instagram, what they are doing when accessing Instagram, and how their response on every activity they mentioned. A total of 50 questionnaires was successfully received back. The questionnaire is then analyzed and chosen to interview to know the users' use pattern.

\section{RESULTS AND DISCUSSION}

The researchers have obtained some data related to the students' attitude on Instagram. Based on the results obtained, it indicates that some behaviors shown by the user indicate mental health disorder symptoms. These behaviors are described in the following discussion.

Addiction is a continuous engagement with an activity in spite of negative consequences (Roberts, Yaya \& Manolis, 2014; Ma'rifatul \& Wiryo, 2015). Someone who is addicted to use instagram will spend most of their time accessing their Instagram account. Some signs showing that someone is addicted to Instagram are: (1) tend to spend more time to use Instagram to be satisfied, (2) not be able to control, reduce, discontinue using Instagram, (3) feel restless, moody, depressed and even angry if quitting Instagram account, (4) tend to online longer than expected (Grace \& Retnowati, 2004).

Some respondents are showing the above addiction signs. One of respondents said "I access my Instagram account for hours in a day; around 12 hours. Within 12 hours, I only scrolled other Instagram users, especially girls' account" (ZA). Likewise, it can be seen from the interview result with a subject (NTN), who said that "I am lost when accessing Instagram, so it is difficult to hang out with my friends because I can interact with my online friends." 
The above responses indicate that some respondents can neither control nor regulate themselves to use Instagram. Self-regulation is one sign indicating that someone has good mental health. Conversely, the inability to control themselves or low self-regulation abilities indicates mental health disorder. Good mental health enables a person direct their own behavior as expected. Schunk and Zimmerman (1998) point out that self-regulation is the use of a process which activates thoughts, behaviors and feelings continuously to achieve predetermined targets.

Comparing love/like obtained on their Instagram posts and others' posts is very significant in this study. The research result indicates that some respondents are unhappy if other people get more like/love on their posts. One respondent said "If someone posted photos and got more likes/ love in her/his account than mine, I will be jealous and make my Instagram post more interesting" (TP). ZA also said the same thing that "Yes, I am disturbed, I am trying to upload more interesting photos so I can exceed my friends' followers".

The self-evaluation maintenance theory can be used to explain the findings above. A person can react positively or negatively on others' success. The reaction can be proud, happy or unhappy and try to restore the feeling of him (Taylor, Peplau \& Sears, 1996). In case the number of posts being loved or liked more than their own posts, a number of respondents explained that they did not like, and even envy of the friends with more loves/likes. This means the Instagram posts with many loves/likes are more popular than those who obtain less love/like. Popularity in this case can be a sign of certain success or achievement.

How is the reaction of other respondents? Most of them responded the same that they want to try to make better video or upload better photos. Some responses include, they need to make new idea to make their posts more useful and interesting, feel a little envy but want to make better posts in order to get more likes/loves. I feel motivated to make interesting content of my posts. However, those who are jealous of other's accomplishments are unhappy with their own.

Basically, everyone has special measures in expressing himself to others. All this is done by each individual to achieve an expected self-image (Jandy, 2010). The desire for self-expression is fair, but it becomes unnatural if this selfexpression is expressed in wrong way; just to get certain attention from others. on respondent said that "my goal to upload my photos on my Instagram account so that other people will see and get their recognition (RN,)."I am seriously making a photo so that my followers can be more, if I have many followers, it means that I am being recognized "( $\mathrm{AB})$. "I feel angry when my followers are less and I am going to unfollow them either" (CA).

Instagram provides a feature where people can edit photos and video, so the result is a better photo or video. With this feature the user can manipulate the images in order to show the message as expected by users of Instagram. A person who is experiencing mental health 
disorders in using instagram will always express himself, whether through photos or videos arranged in such a way. They will try to make others interested in their posts, and someone who is experiencing mental health disorders are usually always expect more about what others think of their posts and easy to feel disappointed if the responses are not as expected This is in line with the statement of RR stating that, 'I will be unhappy if I lost my followers because my objective to create Instagram account is to add friends".

Good mental health is when selfimage or images and attitudes towards oneself is positive. Self image is not dependent on other people's reactions about him. At the moment people feel disturbed by other people's opinions and responses of others actually put their happiness to other people.

Some respondents tend to wait for a response from others after uploading a photo or video in their account. Anxiety arisen because many people won't give love to their post or the response is not as expected. Someone who has an actual good mental health will not be worried and disappointed if it does not respond much. Therefore, if a person feels upset or anxious and even angry responses of others to their posts, for example being criticized, getting not many likes/loves, or suddenly some people are no longer following their accounts (unfollower), there is a sign of low mental health. A number of respondents in this study experienced it, there are some people who are always waiting for a response from others, and if not many people responded he felt disappointed and even angry, really want to get a response from others he will try to make their posts becomes more attractive. It is stated by SJE "I always wait how many people respond to my post, I am very disappointed if my post is not responded, and I will remove my post and then post the more interesting photo, so that many responded" (SJE). In fact, because it was very important to know the response of the other people there are subjects who used a lot of time to wait for the response as presented by JJ "Sometimes I waited and almost kept like that".

The study reinforces a number of studies conducted on the impact of the Instagram use on people mental health, both qualitative and quantitative approaches. For example, Landesi Andarwati (2016) who examines the selfimage in terms of the intensity of Instagram users in class XI of SMAN 9 Yogyakarta. One of the signs of mental health problems is someone will do anything for her/his Instagram post in order to look perfect. Similarly, a study conducted by Bungan Nurika who examines the relationship between selfconcept and self-confidence of teenagers who upload selfie photos on Instagram (Nurika, 2016). Nurika study (2016) showed that the Instagram users will perform a variety of ways for the sake of perfect photo, starting from using the filter, or icon or some other interesting things.

Numerous studies abroad also indicate the same results that the Instagram use can affect the people's mental health. More specifically, Lup, Turb and Rosenthal (2015) found an association between the Instagram uses 
with Simpton depression through mechanisms of social comparison. Social comparison theory explains that when people want to know his qualities but does not have objective information, then someone will compare themselves to others. For Instagram users, how many people love her/his posts can indicate more positive image of himself. To find out by how many loves/likes they obtain, they will try comparing their likes/loves to others.

There are two main factors contributing to the negative impact of Instagram on people's mental health. First, Instagram has many features providing its ease of use drawings, photographs and video to make their post interesting. Communication models like this is a new way to communicate with pictures. In addition to several features, other features enable the users to know how many people respond or like the users' posts. It is a means to represent themselves easily and quickly. The problem is the feature also enables the users see the negative comment or criticism which can insult someone self image. Second, stable emotion and selfregulation can determine the effect of Instagram on the users.

\section{CONCLUSION}

The research results indicated that the students who have Instagram account with high frequency use tend to have the symptoms of a mental disorder characterized by an inaccurate perception about the achievement of selfexistence. Respondents assess and feel their existence based on how many followers clicking 'like' on all posts.
Therefore, they are very serious about making instagram story as a forum to represent themselves to others as desired. Students who use Instagram more often have mental health disorders symptoms such as being addicted of accessing Instagram, feeling uncomfortable with other people's posts, having desire to express themselves, and waiting other people's response after posting photos/videos, feeling disappointed when they do not get many likes or loves from others. This study further shows the necessary efforts and strategies that can enhance the ability of teenagers to use social media in a wise way.

\section{REFERENCES}

Andarwati, I. (2016). Citra Diri Ditinjau dari Intensitas Penggunaan Media Jejaring Sosial

Instagram pada SiswaKelas XI SMA N 9 Yogyakarta. Jurnal Riset Mahasiswa Bimbingan Dan Konseling, 5(3).

Bakker, D., Kazantzis, N., Rickwood, D., \& Rickard, N. (2016). Mental health smartphone apps: review and evidence-based recommendations for future developments. JMIR mental health, 3(1).

Hidayat, R., \&Retnowati, H. S. W. S. (2004). Kontrol diri dan kecenderungankecanduan internet. Humanitas: Jurnal Psikologi Indonesia, 1(1).

Gunawan, F. (2012). Cyberspace dan Bahasa Alay. Kandai: Jurnal Bahasa dan Sastra, 8(2), 137-147.

Kim, J., \& Lee, J. E. R. (2011). The Facebook paths to happiness: Effects of the number of Facebook friends and self-presentation on subjective wellbeing. CyberPsychology, behavior, and social networking, 14(6), 359-364.

Jang, K., Park, N., \& Song, H. (2016). Social comparison on Facebook: Its antecedents and psychological outcomes. Computers in Human Behavior, 62, 147-154.

Laili, F. M. R., Nuryono, W. (2015).Penerapan Konseling Keluarga untuk Mengurangi 
Nuraeni Aprilia Mondoano, Ros Mayasari, Fahmi Gunawan, Instagram and Mental Health of IAIN's

Game Online pada Siswa Kelas VIII SMP Negeri 21 Surabaya.Jurnal BK, 5, 65-72

Lup, K., Trub, L., Rosenthal, L. (2015). Instagram\# instasad?: exploring associations among instagram use, depressive symptoms, negative social comparison, and strangers followed. Cyberpsychology, Behavior, and Social Networking, 18(5), 247-252.

Nurika, B., \& Psi, S. A. S. (2016).Hubungan Antara Konsep Diri Dengan Kepercayaan Diri

Remaja Yang Mengunggah Foto Selfie Di Instagram (Ditinjau Dari Jenis Kelamin Dan Usia) (Doctoral dissertation, Universitas Muhammadiyah Surakarta).

Pratiwi, E. D. (2016). Faktor yang Mempengaruhi Niat Menggunakan Instagram dengan

The Theory of Reasoned Action Menggunakan Amos 21. Jurnal Teknik Komputer, 2(1), 68-77.

Pujazon-Zazik, M., \& Park, M. J. (2010). To tweet, or not to tweet: gender differences and potential positive and negative health outcomes of adolescents' social internet use.American journal of men's health, 4(1), 77-85.

Ramaiah, S. (2003).Kecemasan, bagaimana mengatasi penyebabnya. Jakarta: Yayasan Obor Indonesia

Reece, A. G., \& Danforth, C. M. (2017). Instagram photos reveal predictive markers of depression. EPJ Data Science, 6(1), 15.
Roberts, J., Yaya, L., \& Manolis, C. (2014). The invisible addiction: Cell-phone activities and addiction among male and female college students. Journal of behavioral addictions, 3(4), 254-265.

Schunk, D. H., Zimmerman, B,J, (Eds). (1990). Selfregulated learning: From teaching to selfreflective practice. New York: Guliford Press

Siddiqui, S., \& Singh, T. (2016). Social media its impact with positive and negative aspects. International Journal of Computer Applications Technology and Research, 5(2), 071-075.

Taylor, Shelley,E., Peplau, L.A.,Sears, David O., Psikologi Sosial. Terjemahan Tri Wibowo B.S. Jakarta: Kencana Pernada Media Group, 2009

Wilson, K., Fornasier, S., \& White, K. M. (2010). Psychological predictors of young adults' use of social networking sites. Cyberpsychology, behavior, and social networking, 13(2), 173-177.

https://www.idntimes.com/science/discovery/e ka-supriyadi/riset-instagram-mediasosial-paling-buruk-bagi-kesehatanmental-c1c2/full

https://tekno.kompas.com/read/2017/07/27/1 1480087 /indonesia-penggunainstagram-terbesar-se-asia-pasifik. 